\title{
Role of User Experience through Electronic Word of Mouth About e-commerce Platforms In Re-Patronage Intentions of Shoppers
}

\author{
Navjyoti Singh Negi, Manish Kumar
}

\begin{abstract}
:
Resolution - Previous readings mostly inspect initial shopping intention pertaining to satisfaction and loyalty, but this study will try to explore the possibilities of user experience which is generally get spread by word of mouth.

Outlook/procedure/strategy-A Questionnaire was framed and sent across to the online shoppers, who were 355 in total. Respondents included online buyers who were in the age range of 18 to 65 years.

Eventually, user experience has been used as an indicator and word of mouth as a mediator to understand the re-patronage intentions of shoppers

Outcome/Results-Outcomes from the survey revealed that satisfaction and re-patronage intentions facets impacted shoppers along with the presence of word of mouth and user experience.

Study's constraint/conclusion - The study conducted advises forthcoming papers to take into consideration inclusive investigation, to construct methodology, to formulate online procedure as well as to lay emphasis on stream in finding out the role of user experience and WoM.

Authenticity/importance -The research in itself is one of a kind. A rare effort, with the objective to inspect multiple facets in online shoppers viz. a viz., their perspective and actions which get affected by user experience and WoM.
\end{abstract}

Keywords - Online retailing, Experienced online shoppers, User Experience, word of mouth.

\section{INTRODUCTION}

Re-patronage intention is related to the factors effecting the online purchase of experienced online shoppers (Butler, K.A., 1996). To study the impact of user experience (UX), electronic word of mouth (e-WoM), shopping orientation, and relationship quality on online re-patronage objective amidst proficient online buyers (Dodds, W.B., Monroe, 1995), an online study was conducted and 355 responses were accumulated. The questionnaire and its scales were extracted from earlier conducted researches which were accomplished by different academic intellects. To determine the authencity of this study, scale of the study was investigated first. To measure loads on a particular facet, an authentic trend analysis was applied to seek the pattern on such factors. (Fiore, A.M., Kim, 2005). In order to scale the

Revised Manuscript Received on October 15, 2019.

Navjyoti Singh Negi: Research Scholar at Graphic Era Deemed to $\mathrm{Be}$ University and Assistant Professor, Doon Business School, Dehradun, India

Dr. Manish Kumar: Dean Student Welfare, Graphic Era Deemed to Be University, Dehradun, India. constructs of research and to know about the changeability of each determinant, average factor readings were implied (Goswami, P., 2007). After the measurement model, the second step which was employed was the structural model that took into consideration acceptable (GFI) goodness-of-fit indices model. This model was a fit for the study because (CFI) comparative fit index and the GFI values are not influenced from the size of the sample. Thereafter it was found that this numerical investigation sustains association with attributes such as UX, e-WoM, SO and RQ with ORI.While perceived usefulness along with Perceived Value is what matters the most,for regular online experienced customers, ease of online products and website risk is not a major glitch. E-WoM was determined as an important component in knowing about a customer's behavior, due to a simple reason, customers want less effort to invest in enquiring about a system's convenience. Hence, the findings in this study were different from that of the previous conducted researches examining early adoption of a merchandise in an online ambiance and the intuition of a customer. The findings showcased, experienced online shoppers had a far more contrasting graph than that of the naïve customers. (Basu, R., 2015). In the prior studies involving Online research investigation, the scarcity of literature in terms of varied customer recognition, such as experienced and inexperienced customer band has what led to variations in previous findings. By realizing the thought process of shoppers who are more experienced than that of the naïve shoppers, the online dealers' retailers would be able to focus on distinct target groups and apply separate plans to specific portion of the consumer group, with correct techniques and policies to benefit optimally.

RQ: Are consumers re-patronage expected from UX rudiments through electronic word of mouth in the form of previous involvements?

\section{REVIEW OF THE LITERATURE}

Various studies and researches have tried distinguishing, classifying and defining fundamentals of User Experience. User Experience and electronic word of mouth have fostered greater mark in explicit customer offerings (McCarthy and Wright, 2004). Researchers sightsaw these results and investigated consumer related data values to develop substance for quality offerings in terms of services (Kuniavsky, 2003; Garrett, 2010). In these numerous data collections, electronic word of mouth about products on ecommerce platforms is extensively acquainted for results, because it is easy to 
access informally, and also because the responses can be collected without much hassle. Users' electronic word of mouth constitutes one's keenness, experience shaped after rendering the offering (Park et al., 2013a; Park, 2019). One example would be, (Ksiazek et al. 2016) who propounded a hypotheses in order to provide a better experience in engaging users. Values of datawere poised from online streaming service YouTube, to legalize engaging users in contents, e-contents can be pragmatic with the help of electronic word of mouth for User Experience. (Ziegele et al. 2014) with the help of these accumulated 1580 online statements on daily briefings, with this he initiated that in an interchanging hypotheses "through the help of these comments, an element of User Experience can be collated". (Jang and $\mathrm{Yi}, 2017$ ) tried procuring User Experience attributes from electronic word of mouth, which happens to be theoretic base of this very study. On the basis of about 4400 e-statements collected on mere 3 commodities and services, they mined 4 secondary attributes in User Experience "values that bring in pleasure, user's expectation from the product or service offered, limitations of procuring the same and practical attributes" which involved usage of language based investigation and summing up words. The sorted rudiments briefed about connects amongst fulfilment made by the user, the aforesaid 4 facets of UX and also attributes' contribution in confirming level of contentment. Thus a shopper's feel, the positivity of experiencing a service can be featured strongly into electronic word of mouth, which would help serve a better shopping ambiance for other online buyers (Bhattacharya and Anand, 2019). In tallying, this very research contemplates with the usage of social standards in UXattributes, sinceappearances and interactions in terms of services and borders (Yoo, 2010; Provost and Robert, 2013). One of the best practices to get an insight about shoppers' preferences in particular services or products would be to glance at the numerous previous studies conducted by intellects in this very field, through the help of linguistic trends and word tally. Since studying shoppers accounts provides with insight into specific products of UX consumers' in terms of utilitarian and hedonic attributes, the same could be used to determine the impact of electronic word of mouth via commentaries available in the form of finding of Language patterns and word tallies (Florsheim and Bridges, 2008; Park and Kim, 2019), present researchuses the commentary from language trends/patterns and word counts to investigate various statements present.

Hence, subsequent from that of the previous conducted researches over electronic word of mouth and User Experience, this study aims at developing under listed notionsamidst association of UX facets propounded in the form of users' loyalty and e-WoM.

Hypotheses 1-a. UX can significantly contribute towardsusers' choice of coming back to the interface.

Hypotheses 1-b. e-WoM has a considerable rather important influence towards re-patronage intentions.

Hypotheses 1-c. Mediating effect of e-WoM enhances the impact of UX on re-patronage intentions.

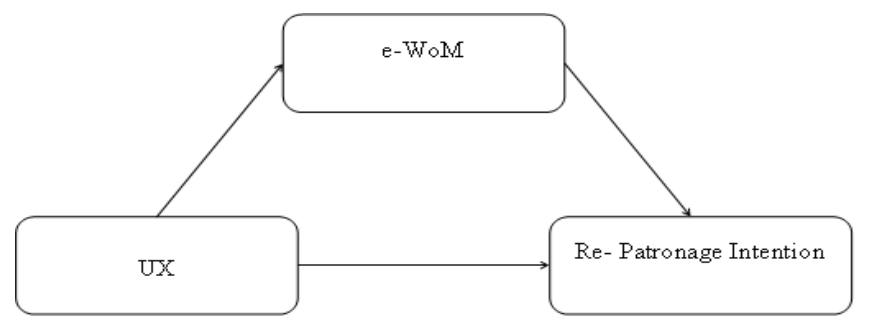

Figure 1: Expressed Chart for the Concept

\section{FORMULATION OF THE QUESTIONNAIRE}

The research's questionnaire has been prepared by keeping in mind the contents of this online survey as well as analyzing the previous studies conducted. It includes one briefed cover, which explains about the need of this research and the methodology applied, the clause of not revealing respondent's identity and keeping in mind the time limit to complete this survey. Objective of this questionnaire is to accumulate data on five major fronts, in a structured research format which would also constitute respondents attributes. Therefore, for the implication of the aforesaid strategy, the questionnaire is in 3 subdivisions, which doesn't includes respondent's demographic constituents. From the aspect of Customer's loyalty, few statements are listed as: "I would like to keep on visiting the same ecommerce platform subsequent events", "For upcoming prospects, this ecommerce platform would be a strong destination I would reckon first having a look into" and "I will look forward into establishing a relationship with the ecommerce platform in the upcoming frame of years". In order to get a statistical idea, these components were scaled in the ranging order of code 1, which means strong discontent to code 5 , which means strong agreement. The codes for measurement are: 1= Very Unlikely, 2= Unlikely, 3= Neutral, 4= Likely, 5= Very Likely (Spreng in 1995), Chiu in (2009) and Reynolds et al. (2012). UX scale was developed on a Likert scale of six by (Laugwitz, B., Schrepp, M. \& Held, T. 2008). Electronic word of mouth can be measured by the scale developed by (ShashaTeng,Kok Wei Khong,WeiWei Goh\& Alain Yee Loong Chong 2014).

(1) Part 3: User Experience (UX)

(2) Part 4: Electronic Word of Mouth (e-WoM)

(3) Part 5: Re- Patronage Intention

In order to differentiate from prior units, a title has been wrote against each unit. Before every subdivision, a direction has also been listed to avoid uncertainty. The questionaries' sent for the online study, returned with 355 responses, or with $73.58 \%$ of response rate. The data procured was used for various findings in this study. Moreover, thissheds light upon the fact, which is, higher degree of divergence is not recognized by samples.To carve out more transparency, mechanisms employedin reconnoitering the specimen's different constituents are several lists for calculated briefing of the procured accounts, illustrations and figures for graphical representation and 
points which are discussed briefly. The human facets/composition constituting final 335 samplesis illustrated in Table 1.1.

\begin{tabular}{|c|c|c|}
\hline Demographics & Respondents' details ( $n=335$ ) & Frequencies \\
\hline \multirow{2}{*}{ Gender } & Male & 216 \\
\hline & Female & 119 \\
\hline \multirow{6}{*}{ Age } & Less than 25 years & 34 \\
\hline & $25-30$ years & 118 \\
\hline & $31-35$ years & 45 \\
\hline & $36-40$ years & 76 \\
\hline & $41-45$ years & 43 \\
\hline & Above 45 years & 19 \\
\hline \multirow{5}{*}{ Experience } & $0-5$ years & 79 \\
\hline & $6-10$ years & 74 \\
\hline & $11-15$ Years & 38 \\
\hline & $16-20$ Years & 86 \\
\hline & Greater than 21 years & 58 \\
\hline \multirow{3}{*}{ Education } & Graduate & 142 \\
\hline & Post graduate & 137 \\
\hline & Any other & 56 \\
\hline \multirow[t]{2}{*}{ Marital Status } & Married & 192 \\
\hline & Un-Married & 143 \\
\hline \multirow[t]{4}{*}{$\begin{array}{l}\text { Monthly House } \\
\text { Hold Income }\end{array}$} & $<\operatorname{INR} 10,000$ & 62 \\
\hline & Rs. $10,000-20,000$ & 49 \\
\hline & Rs. $20,000-30,000$ & 29 \\
\hline & $>$ INR 30,000 & 195 \\
\hline \multirow[t]{3}{*}{ Family Size } & $1-3$ & 202 \\
\hline & $3-5$ & 43 \\
\hline & $5 \&$ More & 50 \\
\hline $\begin{array}{l}\text { Average time } \\
\text { spend on } \\
\text { Internet }\end{array}$ & $<1$ Hour & 122 \\
\hline \multicolumn{3}{|l|}{$\begin{array}{l}\text { Shopping per } \\
\text { week }\end{array}$} \\
\hline & 1 to 2 Hours & 54 \\
\hline & 2to3 Hours & 47 \\
\hline & 3 to 4 Hours & 71 \\
\hline & $>4$ Hours & 41 \\
\hline
\end{tabular}

\section{DETAILED EXAMINATION}

Following para, explains predictors namely,Shoppers' Beliefs, User Experience, Relationship Quality, Electronic word of mouth, Re-Patronage Intention with respect to the detailedvalues obtained, authenticity of those values and reliability of scale. The results help recognizethe values which are out-of-range, to determine means and procure standard deviations, kurtosis and skewness and kurtosis plus cumulative facet relationship.

\section{A. Re-Patronage Intention}

The collated numbers obtained in the study for means, standard deviations, skewness and kurtosis in Re-Patronage Intention has been showcased in table 2.1, whereas a statistical detail of explanatory study on Re-Patronage Intention in Table 2.2. A thorough analysis of the values obtained from skewness and kurtosis hints no terms of equal distribution has been tampered. The cumulative mean number obtained for Re-Patronage Intention items is 3.58, whereas the midpoint is 2.5 , lesser than the result. The output derived clearly states that employees perceive poorly when it is about measuring their client's satisfaction. As propounded by Hair at al., (2010), the authenticity in Re-Patronage Intention measurementis described by the value of Cronbach alpha value, with that of the Re-Patronage Intention value. In this study, it is 0.78 , much above the average of 0.6 and thus not acceptable.

Table 2.1:Results for Means, Standard Deviations, Skewness and Kurtosis in Re-Patronage constituents

\begin{tabular}{|l|l|l|l|l|l|}
\hline \multirow{2}{*}{ Construct } & Item & \multirow{2}{*}{ Mean } & S.D & Sherness & Kurtosis \\
\cline { 2 - 6 } & Code & & & & \\
\hline Re-Patronage & SS1 & 3.69 & 0.742 & -0.199 & -1.152 \\
\hline & SS2 & 3.02 & 0.687 & -1.315 & -0.557 \\
\hline
\end{tabular}

Table 2.2: Explanatory numbers of Re-Patronage Intentions measurements

\begin{tabular}{llllll}
\hline Scale & Minimum & Maximum & Mean & SD & Crophach's Alpha \\
\hline Re-Patronage & 1 & 5 & 3.58 & .66 & .78
\end{tabular}

Table 2.3: Multiple Regression Analysis

\begin{tabular}{|c|c|c|c|c|c|c|c|c|c|}
\hline $\begin{array}{l}\text { ModelDep } \\
\text { endent } \\
\text { Variable }\end{array}$ & $\mathbf{R}$ & \begin{tabular}{|l} 
R \\
Squared
\end{tabular} & $\begin{array}{l}\text { Adjusted } \\
\mathbf{R} \\
\text { Squared }\end{array}$ & $\begin{array}{l}\text { Std. } \\
\text { Error }\end{array}$ & $\begin{array}{l}\text { Sum of } \\
\text { Squares }\end{array}$ & df & $\begin{array}{l}\text { Mean } \\
\text { Square }\end{array}$ & F & Sig. \\
\hline Mobile App & 0.694 & 0.481 & 0.329 & 1.032 & & & & & \\
\hline Regression & & & & & 117.622 & 4 & 15.232 & 14.090 & $\begin{array}{l}.000 \\
8 \%\end{array}$ \\
\hline Residual & & & & & 236.587 & 736 & \begin{tabular}{|l|}
1.081 \\
\end{tabular} & & \\
\hline \begin{tabular}{|l|} 
Total \\
\end{tabular} & & & & & 354.209 & 740 & & & \\
\hline \begin{tabular}{|l|} 
Website \\
\end{tabular} & 0.489 & 0.239 & 0.114 & 0.851 & & & & & \\
\hline Regression & & & & & 9.871 & 4 & 2.267 & 2.504 & $\begin{array}{l}.000 \\
88\end{array}$ \\
\hline Residual & & & & & 175.53 & 737 & 0.905 & & \\
\hline Total & & & & & 185.401 & 741 & & & \\
\hline
\end{tabular}

Foot Note: ${ }^{*} \mathrm{p}<.01, * * \mathrm{p}<.001$. Attributes: Customer's belief, and Relationship Quality. Outcome: User Experience.

The regression model for Mobile app yielded a significant statistic $(\mathrm{F}=14.090, \quad \mathrm{p}<.001) \quad$ (Table 4.42). Significant facets of procuring product/services through mobile app consisted Shoppers perception $(\beta=.42, \quad \mathrm{p}<.001)$, User Experience $(\beta=.32, \quad \mathrm{p}<.01)$, Choice of store variant $(\beta=.28, \quad \mathrm{p}<.001), \quad$ and Relationship Quality $(\beta=.48, \quad \mathrm{p}<.01)$

Results obtained through website by using method of regressionare ( $\mathrm{F}=2.504, \mathrm{p}<.001)$ listed in (Chart 4.42). Important attributes of buying behaviourafter analyzing website were found as Buyer's beliefs $(\beta=.31, \mathrm{p}<.001)$, User experience $(\beta=.20, p<.01)$, and Relationship Quality $(\beta=.22$, $\mathrm{p}<.01)$

and Engin 


$\mid$\begin{tabular}{|l|l|l|l|l|}
\hline MEDIATION RESULT \\
\hline Hypotheses 1 & $\begin{array}{l}\text { (i) User Experience } \rightarrow \text { Re- } \\
\text { Patrongge }\end{array}$ & 0.46 & $\mathrm{P}<0.01$ & Supported \\
\hline Hypotheses 2 & $\begin{array}{l}\text { (ii) User Experience } \rightarrow \text { e- } \\
\text { Weld } \rightarrow \text { Re- Patronage }\end{array}$ & 0.22 & $\mathrm{P}<0.01$ & Supported \\
\hline
\end{tabular}

\section{CONCLUSION}

The research's outcome highlights shopper's reliance on e-WoM influence, when it is about choosing ecommerce platform, a field of study that has received negligible focus in terms of the previous studies conducted. Findings of this research showcases, users tend to vary in their shopping trend because of the fact that there are many variants of UX present in market. One single UX variant can't contribute much when it comes to consultation of shoppers' demands. New age buyers today select an ecommerce variant, go through its attributes in terms of their value for money, time investment and ease of buying. Thus, holding a shopper's patronage within a specific UX variant is considered as a challenging function to accomplish. Due concern should also be given to factors such as word of mouth and UX design, as these facets also influences online buyers. Results also highlight the necessity for an e-WoMconstruct to market products online. Moving further into the research, it exposes the consumers in Indian market of retailing, do get impacted with the demographic composition and this plays a crucial role in stimulatingchoice for a ecommerce retail variant. The study also reckons that choosingaecommerce variant is a tiered course of action, which also relies on electronic word of mouth and existing the demands presented by shoppers. Buying beliefs, User Experience, Electronic Word of Mouth and Quality to deliver expectations are few facets that influences shoppers contentment and subsequently for re-patronage intentions. Electronic word of mouth is another important mode to estimate Re-patronage intention and helps us better understand the link between these two. While formulating UX plans, the study recommends dealers to take into consideration the recent developments that has been going on in e-retailing sector of the economy.

\section{REFERENCES}

1. Ailawadi, K.L., Keller, K.L., "Understanding retail branding: conceptual insights and research priorities", Journal of Retailing, Vol. 80, No.4,

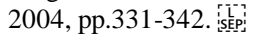

2. Al-Rasheed, S., Zairi M., Ahmed A,M., "Getting in the mind of the customer: An empirical study of consumer behaviour in retailing", Working Paper No.04/12, 2004, Bradford University, School of Management.

3. Baker, J., Grewal, D. and Levy (1992), “An experimental approach to making retail store environmental decisions", Journal ofRetailing, Vol. 68, pp. 445-60.

4. Banerjee, A. and Banerjee, B. (2000), "Effective retail promotion management: use of point of sale information resources", Vikalpa, Vol. 25 No. 4, pp. 51-9.

5. Banerjee, A. and Divakar, S. (2000), "Price threshold in a promotion intensive environment: how consumers optimally make decisions on how much to buy", Decision, Vol. 27 No. 1, pp. 27-58.

6. Bell, D.R., Ho, T-H. and Tang, C.S. (1998), "Determining where to shop: fixed and variable costs of shopping", Journal of Marketing Research, Vol. XXXV, pp. 352-69.

7. Berry, L.L. (1969), "Component of department store image: atheoretical and empirical analysis", Journal of Retailing, Vol. 45, pp. 3-20.

8. Berry, L.L. (2001), "Old pillars of new retailing", Harvard Business Review, Vol. 79 No. 4, pp. 131-7.

9. Bhattacharya, S. and Anand, V. (2019), "What Makes the Indian Youths to Engage with Online Retail Brands: An Empirical Study", Global Business Review, pp. 1-23

10. Bo Daia,, Lou E. Peltonb , "Exploring consumers' skincare retail patronage", Journal of Retailing and Consumer Services, Volume 43, July 2018, Pages 269-277

11. Butler, K.A., 1996. Usability engineering turns 10. Interactions 3 (1), 58-75.

12. Bridges, E., Florsheim, R., 2008. Hedonic and utilitarian shopping goals the online experience. J. Bus. Res. 61, 309-314.

13. Dodds, W.B., Monroe, K.B., Grewal, D., 1991. Effects of price, brand, and storeinformation on buyers' product evaluations. J. Mark. Res., 307-319.

14. Engel, J.F., Blackwell, R.D., Miniard, P.W., 1995. Consumer Behavior Dryder, New York.

15. Fiore, A.M., Kim, J., Lee, H.-H., 2005. Effect of image interactivity technology onconsumer responses toward the online retailer. J. Interact. Mark. 19 (3), 38-53

16. Fornell, C., Larcker, D.F., 1981. Evaluating structural equation models withunobservable variables and measurement error. J. Mark. Res., 39-50.

17. Business Today (1999), "Retail revelations", 22 July-6 August.

18. Hassenzahl, M., Burmester, M. Koller, F., 2003. AttrakDiff: Einfragebogenzur messing wahrgenommenerhedonischer und pragmatischerQualität, Mensch \& Computer, Vieweg TeubnerVerlag, pp. 187-196

19. Huang, T.-L., Hsu-liu, F., 2014. Formation of augmented reality interactive technology's persuasive effects from the perspective of experiential value. Internet Res. 24 (1), 82-109.

20. CII-Mckinsey\& Company (2000), Retailing in India - TheEmerging Revolution, Mckinsey \& Company, Inc., Mumbai,pp. 11-28.

21. Dash, J.F., Schiffman, L.G. and Berenson, C. (1976), "Risk and personality-related dimensions of store choice", Journal of Marketing, Vol. 40, pp. 32-9.

22. Dodge, R.H. and Summer, H.H. (1969), "Choosing between retail stores”, Journal of Retailing, Vol. 45 No. 3, pp. 11-21.

23. Fernandes, M., Gadi, C., Khanna, A., Mitra, P. and Sabbu, N. (2000), "Indian retailing comes of age", McKinseyQuarterly, No. 4, pp. 95-102.

24. Bagozzi, R.P., Gopinath, M., Nyer, P.U., "The role of emotions in marketing", Journal of the Academy of Marketing Science, Vol. 27,

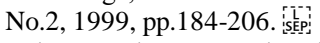

25. Baker, J., Dhruv Grewal., Michael Levy., "An experimental approach to making retail store environmental decisions", Journal of Retailing,

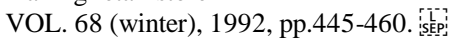

26. Craig, C.S., Ghosh, A., McLafferty, S., "Models of the retail location process, a review", Journal of Retailing, Vol.50, No.4, 1984, pp. 99-112 in

27. Crask, Melvin and Fred Reynolds, "An in-depth profile of the department store shopper," Journal of Retailing, Vol.54 (summer), 1978, pp.23-32. 'E']

28. Cronbach, L., "Coefficient alpha and the internal structure of tests",

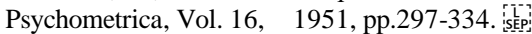

29. Enders, Albrecht; Jelassi, tawfik, "The Converging Business Models of Internet and Bricks-and-Mortar Retailers", European Management Journal, Vol.18, No.5, 2000, pp.542-550

30. Feick, L.F., Price, L.L., "The market maven: a diffuser of marketplace information", Journal of Marketing, Vol.51 (January), 1987, pp.83-97. isepi

31. Fiore, A.M., Yah, X., Yoh, E., "effects of a product display and environmental fragrancing on approach responses and pleasurable experiences", Psychology \& Marketing,

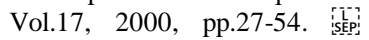

32. Fisher, J.E., "Social class and consumer behaviour: the relevance of class and status", Advances in Consumer

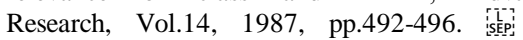

33. Forsythe, S.M., Bailey, A.W., "Shopping enjoyment, perceived time poverty, and time spent shopping", Clothing and Textiles Research Journal, Vol.14, No.1, 1996, pp.185-191. is is-pis

34. Fotheringham, A. S., "Consumer store choice and choice set definition", Marketing Science, Vol.7, No.3, 1988, pp.299-310.

35. Garrett, J.J., 2006. Customer loyalty and the elements of user experience. Design Manag. Rev. 17, 35-39. 
36. Goldman, A., Johnson, JK., "Determinants of search for lower prices: An empirical analysis", Journal of Consumer Research, Vol. 5, No.3, 1978, pp. 176-186 as cited in KiranKarande \& John R Lombard, " Location strategies of broad-line retailers: an imperial investigation', journal of Business Research, Vol.58, No.5, pp. 687-695.

37. Gonzalez-Fernandez A., Bello, L., "The construct 'lifestyle' in market segmentation: the behaviour of tourist consumers", European Journal of Marketing, Vol.36, No.1/2, 2002, pp. 51-86.

38. Goswami, P., "Psychographic segmentation of college-goers of Kolkatta”, IIMB Management Review, Vol.19, No.1, 2007, pp. 41-53.

39. Ksiazek, T.B., Peer, L., Lessard, K., 2016. User engagement with online news: conceptualizing interactivity and exploring the relationship between online news videos and user comments. New Media Soc. 18, 502-520.

40. Jang, J., Yi, M.Y., 2017. Modeling user satisfaction from the extraction of user experience elements in online product reviews. In: Proceedings of the 2017 CHI Conference Extended Abstracts on Human Factors in Computing Systems, pp. 1718-1725 ACM

41. Kahle, LR., Kennedy, P., "Using the list of values (LOV) to understand consumers", The Journal of Consumer Marketing, Vol.6, (Summer), 1989, pp. 5-11.

42. Lumpkin, J.R., Hawes, JM, "Retailing without Stores: an examination of catalog shoppers, "Journal of Business Research, Vol.13, 1985, pp. 139- 151.

43. Laugwitz, B., Schrepp, M. \& Held, T. (2008) Construction and evaluation of a user experience questionnaire. In: Holzinger, A. (Ed.): USAB 2008, LNCS 5298, pp. 63-76.

44. Lumpkin, James R., JM Hawes, "Retailing without Retailing without Stores: an examination of catalog shoppers, "Journal of Business Research, Vol.13, 1985, pp. 139-151. [s]

45. Lumpkin, James R., John, J. Burnett, "Identifying determinants of store type choice of the mature consumer", Journal of Applied Business Research, Vol.8, No.1, 1991, pp. 89-102.

46. McCarthy, J., Wright, P., 2004. Technology as experience. interactions $11,42-43$.

47. Malhotra, NK., "A threshold model of store choice", Journal of Retailing Vol. 59, No.2, 1983, pp. 3-21. [is

48. McDougall, G.H.G., Fry , J.N., "Combining two methos of image measurement", Journal of Retailing,No.50,(1974-1975),pp.53-61 as cited in the Orhan., Erdem., A.BenOumlil., SecilTuncalp,: Consumer values and the importance of User Experience", International journal of Retail \& Distribution Mangement,Vol.27,No.4,1999,pp.137-144.

49. Park, E., 2019. Positive or negative? public perceptions of nuclear energy in South Korea: evidence from big data. Nucl. Eng. Technol. 51, 626-630.

50. Provost, G., Robert, J.-M., 2013. The dimensions of positive and negative user experiences with interactive products. In: International Conference of Design, User Experience, and Usability. Springer, pp. 399-408.

51. RituparnaBasu, Are They Really Different? A Study on Apparel Shoppers' Retail Format Perception in USA and India, Global Business Review, vol. 16, 1: pp. 123-136.

52. Ruby R.Dholakiaa, NikhileshDholakia, AtishChattopadhyay , "Indigenous marketing practices and theories in emerging economies: Consumer behavior and retail transformations in India", Journal of Business Research Volume 86, May 2018, Pages 406- 415

53. Spreng, R.A., Harrell, G.D., Mackoy, R.D., 1995. Service recovery: Impact on satisfaction and intentions. Journal of Services Marketing 9 (1), 15-23.

54. ShashaTengKok Wei Khong Wei Wei Goh Alain Yee Loong Chong, (2014),"Examining the antecedents of persuasive eWOM messages in social media", Online Information Review, Vol. 38 Iss 6 pp. 746 - 768

55. TamasKoplyay, Doug Lloyd, AbdelkaderJazouli, Brian Mitchell (2015), "The Strategic Marketing Function In Dynamic Markets", Polish Journal of Management Studies 2015; 12 (1) pp. 59-76

56. Taylor, R., "Top of mind: saving America's grocers", Brand week, Vol.44, No.18, 2003, pp.22-32.

57. Vijayasarathy, L.R., "Shopping orientations, product types and internet shopping intentions", Electronic Markets: the International Journal of Electronic Commerce \& Business Media, Vol.13, No.1, 2003 pp.67-79.

58. Williams, T.G., "Social class influence on purchase evaluation criteria", iL
Zire

59. Ziegele, M., Breiner, T., Quiring, O., 2014. What creates interactivity in online news discussions? an exploratory analysis of discussion factors in user comments on news items. J. Commun. 64, 1111-1138 